\title{
The Ruling of the Bundesverfassungsgericht in PSPP - An Inquiry into its Repercussions on the Economic and Monetary Union
}

\author{
Bundesverfassungsgericht 5 May 2020, 2 BvR 859/15 and others, PSPP
}

\author{
Paul Dermine ${ }^{1}$
}

\section{INTRODUCTION}

The 'German court has set a bomb under the EU legal order'. ${ }^{2}$ This is certainly no overstatement from Martin Sandbu, influential columnist for the Financial Times, considering the explosive nature of the final ruling issued by the German Federal Constitutional Court in the Weiss saga. ${ }^{3}$ Beyond its inappropriate timing and aggressive tone, the decision has struck commentators by its many structural ramifications for the European polity. We might still lack hindsight to critically assess the legacy of the PSPP ruling, and the deeper evolutions it will set in motion. There is no doubt, however, that the deflagration will be profoundly felt in the European Union constitutional order, the European judicial landscape and the Eurozone. Certainly,

${ }^{1}$ J.D. (UCLouvain), M.A. (College of Europe), LL.M. (NYU), PhD (Maastricht University/ KULeuven), Max Weber Fellow (EUI). The author wishes to thank the anonymous reviewers for their insightful comments.

${ }^{2}$ M. Sandbu, 'German Court Has Set a Bomb under the EU Legal Order', Financial Times, 5 May 2020.

${ }^{3}$ BVerfG 5 May 2020, 2 BvR 859/15, 2 BvR 1651/15, 2 BvR 2006/15, 2 BvR 980/16. In order to distinguish it from the Court of Justice's ruling in the same case, this contribution will refer to the Bunderverfassungsgericht's ruling as the PSPP ruling.

European Constitutional Law Review, 16: 525-551, 2020

(C) The Author(s), 2020. Published by Cambridge University Press on behalf of European Constitutional Law Review. This is an Open Access article, distributed under the terms of the Creative Commons Attribution licence (http://creativecommons.org/licenses/by/4.0/), which permits unrestricted re-use, distribution, and reproduction in any medium, provided the original work is properly cited. doi: $10.1017 / S 1574019620000280$ 
this is a landmark decision, which will quickly make its way into European law textbooks.

This ruling raises many fundamental questions, as to the state of judicial dialogue in the EU and the institutional position of the European Court of Justice, the authority of European law and the sustainability of founding principles of our discipline, such as primacy, uniform application or constitutional identity. The wider impact of the ruling on the political economy of the Union, or on its ability to efficiently preserve its founding values in member states where they are under attack, have also come into question.

Beyond these systemic repercussions, the ruling will also have a lasting impact on its main subject-matter, i.e. the Economic and Monetary Union and its legal and institutional ordering. The ruling indeed questions several founding paradigms of the constitutional architecture of the Eurozone. It is undeniable that its weight on the future trajectory of monetary and fiscal integration in Europe will be felt for years to come.

This contribution will approach and assess the PSPP ruling from this specific perspective. It first examines the ruling's background, and presents the Bundesverfassungsgericht's key findings and reasoning. It then focuses on the main consequences of the PSPP ruling for the Economic and Monetary Union. Successively, it analyses the ruling's potential impact on the allocation of powers in the Eurozone, on the institutional position of the European Central Bank, and on the wider trajectory of Eurozone integration and the further development of the fiscal pillar.

\section{BACKGROUND TO THE BundesVerfassungsgericht's PSPP RULING}

This ruling is to be read against the background of two broader evolutions which have shaped the trajectory of the Economic and Monetary Union and its law over the past decade: the metamorphosis of the European Central Bank through the development of new forms of 'unconventional' monetary policy, and the increased 'judicialisation' of Eurozone governance. The Eurocrisis first, and the current pandemic situation, have placed the European Central Bank at the centre of the institutional response to these existential tests. These exceptional events forced the central bankers in Frankfurt to leave the realm of standard monetary policy, to take on new roles (as chief financial supervisor of the Eurozone under the Single Supervisory Mechanism or as a member of the Troïka for example) and to experiment with novels forms of monetary policy through so-called 'non-standard' programmes (such as government bonds-buying schemes or wider quantitative easing 
measures). ${ }^{4}$ The transformation of the European Central Bank and monetary policy, and more generally the profound overhaul that the Eurozone underwent as a result of a decade of crisis-induced reforms, have generated serious constitutional tensions, which have in turn prompted European judiciaries to step in. Recent years have been marked by an unprecedented level of judicial involvement, both national and supranational, in the economic and monetary affairs of the Eurozone, and have turned courts into central players in the Eurozone's institutional system. The Bundesverfassungsgericht's PSPP ruling is the latest of a long series of judgments that have accompanied the progressive metamorphosis of the European Central Bank, and assessed the legality of the transformations at play.

At the centre of the dispute lies an unconventional monetary policy programme which perfectly embodies the recent mutations of the European Central Bank: the 'public sector purchase programme' (PSPP). The programme was the central piece of the wider 'asset purchase programme', ${ }^{5}$ an ambitious quantitative easing plan designed to ease financial and monetary conditions through massive liquidity injections, and support a return to a $2 \%$ inflation rate. The PSPP was set up and organised by Decision No. 2015/774 of the European Central Bank Governing Council, ${ }^{6}$ and was subsequently amended on several occasions. ${ }^{7}$ Under the PSPP, the European Central Bank and the national central banks of the Eurosystem commit to the purchase of public bonds on the secondary markets. Eligible assets primarily include 'debt securities issued by central, regional or local governments of a member state whose currency is the euro, recognised agencies located in the euro area, international organisations located in the euro area and multilateral development banks located in the euro area' ${ }^{8}$ Contrary to previous European Central Bank programmes, and most notably

\footnotetext{
${ }^{4}$ See T. Beukers, 'The New ECB and Its Relationship with the Eurozone Member States Between Central Bank Independence and Central Bank Intervention', 50 CMLR (2013) p. 1579.

${ }^{5}$ The asset purchase programme also included the corporate sector purchase programme, the asset-backed securities purchase programme and the third covered bond purchase programme.

${ }^{6}$ ECB, Decision No. 2015/774 of 4 March 2015 on a secondary markets public sector asset purchase programme, OJ (2015) L121/20.

${ }^{7}$ ECB, Decision No. 2015/2101 of 5 November 2015 amending Decision 2015/774 on a secondary markets public sector asset purchase programme, OJ (2015) L303/106; ECB, Decision No. 2015/2464 of 16 December 2015 amending Decision 2015/774 on a secondary markets public sector asset purchase programme, OJ (2015) L344/1; ECB, Decision No. 2016/702 of 18 April 2016 amending Decision 2015/774 on a secondary markets public sector asset purchase programme, OJ (2016) L121/24; ECB, Decision No. 2017/100 of 11 January 2017 amending Decision 2015/774 on a secondary markets public sector asset purchase programme, OJ (2017) L16/51. The Decision was recast in February 2020: ECB, Decision No. 2020/188 of 3 February 2020 on a secondary markets public sector asset purchase programme, OJ (2020) L39/12. For the sake of clarity, references will be made to this recast decision.

${ }^{8}$ Decision No. 2020/188, supra n. 7, Art. 3(1).
} 
the outright monetary transactions programme, PSPP is not selective, and applies to all Eurozone member states. Eligible securities are to have a remaining maturity of between one and thirty years, ${ }^{9}$ and originate from issuers with a 'credit quality assessment of at least Credit Quality Step 3 in the Eurosystem's harmonized rating scale. ${ }^{10}$ The Decision also provides for a so-called 'blackout period', i.e. a minimum amount of time which must lapse between the issue of a security on the primary market and its purchase by the Eurosystem on the secondary market, to be further determined by the Governing Council. ${ }^{11}$ The PSPP contains purchase limits for the different types of debt securities it covers, ${ }^{12}$ and foresees, with regard to portfolios allocation, that $10 \%$ of net purchases should be towards securities issued by international organisations and multilateral development banks, while the remaining 90\% should be towards securities issued by state or sub-state entities. ${ }^{13}$ The implementation of PSPP is structured in such a way that $10 \%$ of the purchases are made directly by the European Central Bank, and the remaining $90 \%$ are carried out in a decentralised manner by the national central banks, following a distribution mirroring the European Central Bank's capital key. ${ }^{14}$ In principle, each national central bank assumes the risks associated with its purchase. A risk-sharing regime, however, applies to $20 \%$ of the purchases, namely the $10 \%$ of securities directly purchased by the European Central Bank, and the 10\% of securities issued by European institutions and acquired by national central banks. ${ }^{15}$ Securities purchases under the asset purchase programme were conducted without interruption between March 2015 and December 2018, with monthly purchase volumes oscillating between $€ 80$ and 15 billion. The programme was temporarily suspended between January and October 2019, and then restarted in November 2019, at a monthly pace of $€ 20$ billion. In total, the Eurosystem has acquired some $€ 2,743$ billion of assets under the asset purchase programme, a huge share (€2,218 billion) of which consist of public bonds purchased under PSPP. ${ }^{16}$ The proportions of the

\footnotetext{
${ }^{9}$ Ibid., Art. 3(3).

${ }^{10}$ Ibid., Art. 3(2). This credit quality threshold is the lowest level of investment grade rating under the European Central Bank's own rules (ECB, 'Eurosystem Credit Assessment Framework', 6 May 2020, 〈https://www.ecb.europa.eu/paym/coll/risk/ecaf/html/index.en.html $\rangle$, visited 23 October 2020. This threshold can, moreover, be suspended by the Governing Council (Decision No. 2020/188, supra n. 7, Art. 3(2)(d)).

${ }^{11}$ Decision No. 2020/188, supra n. 7, Art. 4.

${ }^{12}$ Ibid., Art. 5.

${ }^{13}$ Ibid., Art. 6(1).

${ }^{14}$ Ibid., Art. 6(2)(4).

${ }^{15}$ The relevant Decision was never published. See, however, ECB, 'ECB adds corporate sector purchase programme (CSPP) to the asset purchase programme (APP) and announces changes to APP', 10 March 2016, 〈https://www.ecb.europa.eu/press/pr/date/2016/html/pr160310_2.en. html $\rangle$, visited 23 October 2020 .
} 
programme are simply unprecedented, and have turned the Eurosystem, by far, into the largest creditor of euro area member states.

PSPP, as the perfect embodiment of the unconventional monetary policy deployed by the European Central Bank in reaction to the Eurozone crisis, sparked a massive amount of economic and political controversy. It was therefore no surprise to observers when PSPP was judicially challenged, in none other than Germany, where attachment to an orthodox approach to central banking remains strong in economic and political circles. As had happened for the outright monetary transactions programme, a large number of claimants lodged complaints against PSPP before the Bundesverfassungsgericht in Karlsruhe. In essence, and along similar lines to the Gauweiler saga, they claimed: (i) that PSPP exceeded the mandate enshrined in Article 127 TFEU and went beyond the monetary powers conferred on the European Central Bank by the EU Treaties; and (ii) that it contravened the prohibition on monetary financing consecrated in Article 123 TFEU. Altogether, these breaches would amount to a violation of the German constitutional identity, as including the right to vote and the budgetary autonomy of the Bundestag. ${ }^{17}$ Following the precedent set in Gauweiler, ${ }^{18}$ the Bundesverfassungsgericht stayed the proceedings, and made its second-ever reference for a preliminary ruling to the Court of Justice. ${ }^{19}$ The five questions asked by the Bundesverfassungsgericht revolved around: (i) the compatibility of the programme, and some of its defining features, with the prohibition on monetary financing; (ii) the programme's compliance with the European Central Bank mandate and the legality of its economic policy effects; and (iii) the repercussions that potential national central bank recapitalisation might have in terms of risk-sharing.

In a ruling which broadly followed the Opinion of Advocate General Wathelet, ${ }^{20}$ and largely inspired by its earlier findings in the Gauweiler case, ${ }^{21}$ the Court of Justice found PSPP compatible with EU law. ${ }^{22}$ On the question of competence, the Court ruled that PSPP pursues the objective of price stability

\footnotetext{
${ }^{16}$ Figures and data can be found at ECB, 'Asset Purchase Programmes', 〈https://www.ecb.europa. eu/mopo/implement/omt/html/index.en.html $\rangle$, visited 23 October 2020.

${ }^{17}$ As they flow from Arts. 20(1), 23(1), 38(1) and 79(3) of the German Constitution.

${ }^{18}$ In this regard, see Bundesverfassungsgericht 14 January 2014, 2 BvR 2728/13, 2 BvR 2729/13,

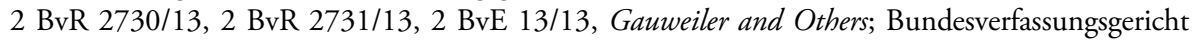
21 June 2016, 2 BvR 2728/13, 2 BvR 2729/13, 2 BvR 2730/13, 2 BvR 2731/13, 2 BvE 13/13, Gauweiler and Others.

${ }^{19}$ Bundersverfassungsgericht 18 July 2017, 2 BvR 859/15, 2 BvR 1651/15, 2 BvR 2006/15, 2 BvR 980/16 Weiss and Others. For an extensive analysis of the Bundesverfassungsgericht's referral, see A. Lang, 'Ultra Vires Review of the ECB's Policy of Quantitative Easing: An Analysis of the German Constitutional Court's Preliminary Reference Order in the PSPP Case', 55 CMLR (2018) p. 923.

${ }^{20}$ Opinion of AG Wathelet, 4 October 2018, Case C-493/17, Weiss and Others.

${ }^{21}$ ECJ 16 June 2015, Case C-62/14, Gauweiler and Other v Deutscher Bundestag.
} 
and relies on one of the monetary policy instruments provided for by primary law, thereby falling within the sphere of monetary policy. ${ }^{23}$ The Court, moreover, considered that the economic policy effects produced by PSPP cannot question its monetary nature, as these effects are inevitable and remain indirect. ${ }^{24}$ The Court also examined the proportionality of the programme and considered that, in spite of its extraordinary features (most notably the volumes covered, its length or the risks entailed), it complies with the three conditions of suitability, necessity and proportionality stricto sensu. ${ }^{25}$ Turning to the issue of PSPP's compatibility with Article 123 TFEU, the Court found no element showing that the programme effectively circumvents the prohibition of monetary financing consecrated by the Treaties. The Court indeed considered that the PSPP includes sufficient safeguards guaranteeing that private operators on the secondary markets will not have the de facto certainty that the bonds they had acquired from member states will subsequently be purchased by the Eurosystem. Key in that regard is the observance of a blackout period, the variability of purchase volumes and the purchase limits built into the programme. ${ }^{26}$ Furthermore, the Court found that the temporary nature of the programme, its limited volume, purchase limits and stringent eligibility criteria prevent it from reducing the impetus for member states to pursue sound budgetary policies. ${ }^{27}$ Finally, the Court deemed the fifth question, on risk-sharing under PSPP, hypothetical and refused to answer it. ${ }^{28}$

\section{The Ruling of the Bundesverfassungsgericht IN PSPP: KeY FINDINGS AND REASONING}

On 5 May 2020, the Bundesverfassungsgericht issued its final ruling in the PSPP case. ${ }^{29}$ The decision stands as the latest intervention in the intensive dialogue that the Bundesverfassungsgericht and the Court of Justice started in 2014 on the European Central Bank's monetary policy and the question of power allocation in the Economic and Monetary Union. The least the external observer can say is that with this ruling, the judges in Karlsruhe decided to raise their voices against their Luxembourg counterparts, and the central bankers of Frankfurt.

\footnotetext{
${ }^{22}$ ECJ 11 December 2019, Case C-493/17, Weiss and Others. For an extended analysis, see A. Bobic and M. Dawson, 'Quantitative Easing at the Court of Justice - Doing Whatever it Takes to Save the Euro: Weiss and Others', 56 CMLR (2019) p. 1005.

${ }^{23}$ Ibid., $\$ \$ 53-57$; $\$ \$ 68-70$.

${ }^{24}$ Ibid., $\$ \$ 58-67$.

${ }^{25}$ Ibid., $\$ \$ 71-100$.

${ }^{26}$ Ibid., \$\$ 109-128.

${ }^{27}$ Ibid., $\$ \$ 129-144$.

${ }^{28}$ Ibid., \$\$ 159-167.

${ }^{29}$ Supra n. 3.
} 
The ruling is formally addressed to the German Bundestag and the Federal Government and finds that these two organs have violated the claimants' constitutional rights to vote and to democratic self-determination, and fallen short of their responsibility with regard to European integration (Integrationsverantwortung) by failing to guarantee the compliance of European Central Bank action with the Treaty framework. ${ }^{30}$

The Bundesverfassungsgericht's assessment primarily consists of ultra vires review (at times combined with identity review), and focuses on two issues: PSPP's compliance with the European Central Bank's mandate and the competence allocation system established by the Treaties, and PSPP's potential circumvention of the prohibition on monetary financing (Article 123 TFEU).

On the first matter, ${ }^{31}$ the Bundesverfassungsgericht proceeded in a two-step process. First, ${ }^{32}$ it examined the Court of Justice's assessment in Weiss, to conclude that the delimitation of competences undertaken is simply untenable, and that it therefore does not consider itself bound by the findings of the Court, which exceed its mandate under Article 19(1) TEU. ${ }^{33}$ The Bundesverfassungsgericht took particular issue with the Court of Justice's strictly teleological approach to arbitrate competence conflicts in the Eurozone and separate the economic from the monetary policy spheres, and its lack of account for the principle of proportionality and the practical effects of European Central Bank action. Indeed, crucial in the Bundesverfassungsgericht's finding that the assessment from Luxembourg was 'not comprehensible ${ }^{34}$ and 'objectively arbitrary ${ }^{35}$ was its disregard for the actual effects of PSPP, and its sole reliance on the monetary objective proclaimed by the European Central Bank. ${ }^{36}$ Such disregard was deemed methodologically untenable: ${ }^{37}$ not only did it fully deprive the principle of proportionality of its corrective function, but it also rendered the principle of conferral meaningless. ${ }^{38}$ The Bundesverfassungsgericht was highly critical of the very loose standard of review applied by the Court of Justice which, combined with the European Central Bank's independence, would jeopardise the right to effective judicial protection. ${ }^{39}$ For the Bundesverfassungsgericht, the Court of Justice's approach 'allows the ESCB to conduct economic policy as long as the ECB asserts that it uses the means set out

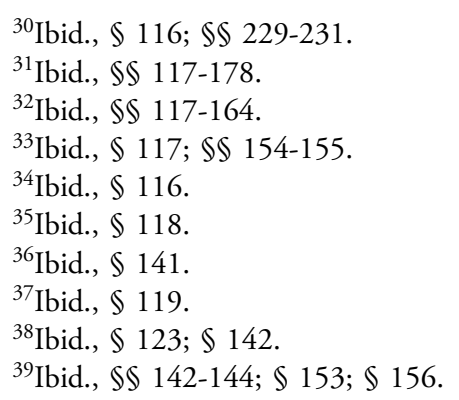


or provided for in the ESCB Statute ... and that it aims to achieve the inflation target fixed by the ECB itself'. ${ }^{40}$ By accepting the monetary objective proclaimed by the European Central Bank 'as fact without further scrutiny and without regard to foreseeable and/or intended ... consequences of the programme in the areas of economic and fiscal policy', Luxembourg would de facto afford the European Central Bank a 'competence to decide on its own competences' ${ }^{41}$ thus paving the way for a 'continual erosion of Member State competences' ${ }^{42}$ in the field of economic and fiscal policy. By allowing the European Central Bank to use its monetary mandate 'to disguise what essentially constitutes an economic and fiscal policy agenda', ${ }^{43}$ the Court of Justice would have abandoned the cardinal distinction between economic and monetary policy, ${ }^{44}$ and make a mockery of the very idea of conferred competences in the Union.

Having dismissed the Court's findings in Weiss on the nature and the proportionality of PSPP, the Bundesverfassungsgericht moved on to conduct its own review, ${ }^{45}$ and concluded that the PSPP violates the principle of proportionality in a structurally significant way, and thereby constitutes an ultra vires act. ${ }^{46}$ While the Bundesverfassungsgericht was convinced by PSPP's suitability, and its ability to contribute to tackling the issue of persistent low interest rates in principle, ${ }^{47}$ it had problems with the fact that the European Central Bank did not seem to have considered the economic policy effects resulting from PSPP, nor to have balanced them against the monetary policy objective pursued. For the Bundesverfassungsgericht, particularly at stake were the effects of PSPP on member states' financing conditions and the significant easing of the fiscal policy terms under which they operate, its impact on balance sheets in the banking sector, the bubbles it might create, the unviable companies it might allow to stay on the markets, and its wider influence on the stability of financial markets and the position of savers, share-holders or real estate owners. ${ }^{48}$ For the Bundesverfassungsgericht, proportionality required the European Central Bank to balance these effects against the monetary benefits of PSPP. But since it is 'not ascertainable that any such balancing was conducted', the court found it impossible to review compliance with the principle of proportionality and, more generally, with the European Central Bank's mandate and the Union's order of

\footnotetext{
${ }^{40}$ Ibid., $\$ 133$.

${ }^{41}$ Ibid., $\$ 136$.

${ }^{42}$ Ibid., $\$ 156$.

${ }^{43}$ Ibid., $\$ 137$.

${ }^{44}$ Ibid., $\$ 162$.

${ }^{45}$ Ibid., $\$ 164-178$.

${ }^{46}$ Ibid., $\$ 165$.

${ }^{47}$ Ibid., $\$ 166$.

${ }^{48}$ Ibid., $\$ \$ 170-175$.
} 
competences. ${ }^{49}$ Since these breaches were 'structurally significant', ${ }^{50}$ PSPP must be deemed ultra vires until it was proven to be proportionate.

The second matter on which the PSPP ruling focused was PSPP's compliance with the prohibition on monetary financing consecrated in Article 123 TFEU. Unlike for its assessment on the first matter, the Bundesverfassungsgericht followed the Court of Justice in finding that the purchases carried out under PSPP did not manifestly circumvent the prohibition. ${ }^{51}$ The programme indeed included several safeguards which guaranteed that member states and market operators can ultimately never be certain that specific bonds will be bought by the Eurosystem. Key in this assessment were the limits on purchase volumes, the distribution of these volumes among central banks according to an objective criterion, the sole reliance on aggregate information, the principled observance of a black-out period, the eligibility policy of the Eurosystem and the temporary nature of the programme. ${ }^{52}$ Such validation, however, did not prevent the Bundesverfassungsgericht from expressing serious concerns about the Court of Justice's assessment, and PSPP's compliance with Article 123 TFEU. ${ }^{53}$ Overall, the Bundesverfassungsgericht deplored the deferential approach of the Court of Justice, and the loose scrutiny to which the Bank's assertions are subject, which would ultimately render some of the safeguards largely ineffective. ${ }^{54}$ These concerns were particularly pregnant for the prohibition of prior announcement, the black-out period, the holding of bonds until maturity and the requirement to decide on an exit strategy.

In the light of these conclusions, and considering the ultra vires nature of PSPP, the Bundesverfassungsgericht mandated the Federal Government and the Bundestag to take the necessary steps to restore adherence to the European integration agenda (Integrationsprogramm). They were thus given three months to seek assurances from the European Central Bank as to the Programme's proportionality. ${ }^{55}$ Failing that, the Bundesbank may need to end its participation in the Programme. ${ }^{56}$

${ }^{49}$ Ibid., $\$ 176$.

${ }^{50}$ Ibid., $\$ 178$.

${ }^{51}$ Ibid., $\$ \$ 197-198 ; \$ 216$.

${ }^{52}$ Ibid., $\$ \$ 198-212$.

${ }^{53}$ Ibid., $\$ \$ 184-196$.

${ }^{54}$ Ibid., $\$ 184, \$ 189, \$ 214$.

${ }^{55}$ Ibid., $\$ \$ 232-234$.

${ }^{56}$ Following a transitional period of no more than three months allowing for the necessary coordination with the ESCB, the Bundesbank may thus no longer participate in the implementation and execution of [PSPP] ... unless the ECB Governing Council adopts a new decision that demonstrates in a comprehensible and substantiated manner that the monetary policy objectives pursued by the ECB are not disproportionate to the economic and fiscal policy effects resulting from the programme' (ibid., $₫ 235$ ). 
The ruling was coldly received in the EU institutional sphere, and prompted a series of strong reactions. On 5 May 2020, the European Central Bank stated that it took note of the Bundesverfassungsgericht's decision, and remained fully committed to its mandate. ${ }^{57} \mathrm{~A}$ few days later, the Court of Justice issued a rather unusual press release recalling the binding nature of its rulings, the importance of the uniform application of EU law, and its exclusive jurisdiction vis-à-vis European Central Bank acts. ${ }^{58}$ The Commission voiced similar concerns through a statement by its President. ${ }^{59}$ It remains to be seen whether it will eventually launch infringement proceedings against Germany. German institutions, in positive collaboration with the European Central Bank, ${ }^{60}$ also formally reacted to the Bundesverfassungsgericht's ruling. Finance Minister Scholz first, ${ }^{61}$ then the Bundestag in a vote, ${ }^{62}$ followed by the Bundesbank through its President Weidmann ${ }^{63}$ took the view that the European Central Bank's assessment had met the requirements laid out by the Bundesverfassungsgericht, and supported the proportionality of PSPP, paving the way for an internal solution to the crisis. It now remains to be seen whether this will satisfy the Bundesverfassungsgericht itself, should the case be reopened by the original claimants.

The following paragraphs focus on the repercussions of the PSPP ruling on its main subject-matter, i.e. the Economic and Monetary Union and its legal and institutional ordering. Successively, we analyse the ruling's impact on the allocation of powers in the Eurozone and the cardinal distinction between monetary and economic policy, on the institutional position of the European Central Bank and the principle of central banking independence, and on the wider trajectory of Eurozone integration and the further development of the fiscal pillar.

\footnotetext{
${ }^{57}$ See the ECB press release, 5 May 2020, 〈https://www.ecb.europa.eu/press/pr/date/2020/html/ ecb.pr200505 00a09107a9.en.html), visited 23 October 2020.

${ }^{58} \mathrm{ECJ}$, 'Press release following the judgement of the German Constitutional Court of 5 May 2020', 8 May 2020, No. 58/20, 〈https://curia.europa.eu/jcms/upload/docs/application/pdf/ 2020-05/cp200058en.pdf), visited 23 October 2020.

${ }^{59}$ European Commission, 'Statement by President Von der Leyen', 10 May 2020, Statement/20/ 846, 〈https://ec.europa.eu/commission/presscorner/detail/en/statement_20_846), visited 23 October 2020.

${ }^{60}$ Even though it did not adopt a new decision, the ECB released a certain number of documents, including several accounts of Governing Council meetings and technical notes, on the effects of PSPP.

${ }^{61}$ A. Rinke, 'ECB Stimulus Plan Meets Court Requirements', Reuters, 29 June 2020.

62‘Bundestag: EZB hat Karlsruher Vorgaben zu Anleihe-käufen erfüllt', 2 July 20202, 〈https:// www.bundestag.de/dokumente/textarchiv/2020/kw27-de-anleihekaeufe-703660, visited 23 October 2020.

${ }^{63} \mathrm{C}$. Siedenbiedel, 'Weidmann sieht Forderungen des Verfassungsgerichts als erfüllt an', FAZ, 3 August 2020.
} 


\section{Delineating European Central Bank competences: power allocation in the ECONOMic and Monetary Union and the RISK OF COMPETENCE CREEP}

\section{The problematic distinction between monetary and economic policy}

Since the Maastricht Treaty, the allocation of powers in the Economic and Monetary Union has relied on a structural distinction between economic policy, which remains a matter of national sovereignty, with policy coordination occurring at the EU level (Article 5 TFEU), and monetary policy, which is exclusively devolved to the Eurosystem on the basis of a mandate geared towards the preservation of price stability (Article 3(1)(c) TFEU and Article 127(1) TFEU). From the outset, this summa divisio has raised serious difficulties. Not only do the Treaties fail to provide a clear delineation between the two policy fields, but the distinction (at least in its strictest variant) is regarded as somewhat artificial by political economists. They are prone to highlight the de facto interdependencies and spillovers between economic and monetary policy, and the practical impossibility of strictly assigning policy measures to either of the two domains. ${ }^{64}$ These difficulties have allowed a grey zone to develop, where the economic, the fiscal and the monetary meet and become difficult to disentangle. Over the past decade, this grey zone has generated serious constitutional tensions as the existential test of the Eurozone crisis (and the recent pandemic) prompted the Union and its member states to venture into the unknown, and experiment with the limits of their respective powers in the monetary and economic field. This challenging environment has given the Court of Justice several opportunities to clarify the allocation of competences in the Economic and Monetary Union, and to further make sense of the de facto intertwinement of monetary and economic policy.

As is well-known, the Court of Justice, first in Pringle, then in Gauweiler and Weiss, continuously and unambiguously favoured a functional (or purposive) approach, under which it is the objective pursued by a measure which determines

\footnotetext{
${ }^{64}$ The institutional architecture of the Economic and Monetary Union as agreed in Maastricht was deeply influenced by neoclassical macroeconomic theory, which advocated for a clear division of responsibilities in the field of monetary and economic policy (the 'assignments' approach) and institutional differentiation. In this regard, see O. Issing, 'On Macroeconomic Policy Co-Ordination in EMU', 40 JCMS (2002) p. 345; A. Alesina and O. Blanchard, 'Defining a Macroeconomic Framework for the Euro Area', in Monitoring the European Central Bank, vol. 3 (Center for Economic Policy Research 2001) p. 3. These views are increasingly questioned among macroeconomists, who now predominantly favour a more integrated approach inspired by Keynesian theories. For an overview, see P. Foresti, 'Monetary and Fiscal Policies Interaction in Monetary Unions', 32 Journal of Economic Surveys (2018) p. 226.
} 
its monetary or economic nature. ${ }^{65}$ In applying this teleological criterion, the Court has favoured a light-touch approach, marked by clear deference to the European Central Bank's self-determination and discretion in interpreting its own monetary mandate (characterised as highly complex and technical). This purposive stance has, however, progressively been complemented by procedural review, structured around the duty of care and the duty to state reasons. ${ }^{66}$ A crucial consequence of this teleological approach is that the side effects of a measure genuinely pursuing an economic or a monetary objective are not seen as determinant and likely to question its legal qualification as an economic or monetary policy measure. The Court has consistently recognised the de facto interdependence of the two pillars, ${ }^{67}$ and the possibility of cross-pillar effects. ${ }^{68}$ In its case law, the Court makes a principled distinction between indirect effects, which are to remain immaterial and cannot validly challenge the purposive qualification of a measure as either economic and monetary, and direct effects, which should, on the contrary, prompt such requalification. However, this distinction has never been operationalised by the Court of Justice, and has so far only played a rhetorical role in the Court's assessment.

Interestingly, in its preliminary ruling request on PSPP, the Bundesverfassungsgericht had urged the Court of Justice to further flesh out the notion of indirect effect, suggesting that economic policy effects of monetary measures might only qualify as indirect if unforeseeable and unintended. ${ }^{69}$ In Weiss, the Court of Justice took the opposite view, considering that indirect effects could constitute foreseeable consequences of a measure, knowingly accepted at the time of its adoption. ${ }^{70}$ It failed, however, to further clarify this important notion by putting an alternative test forward. The concept thus remained non-operational

${ }^{65}$ See Gauweiler, supra n. 21, $\$$ 46; Weiss, supra n. 22, $\$ 53$; ECJ 27 November 2012, Case C-370/12, Thomas Pringle v Government of Ireland and Others, $\$ \$ 53$ and 55. The Court's approach is a direct extension of its general 'centre of gravity' doctrine, famously inaugurated in the Tobacco Advertising ruling (ECJ 5 October 2000, Case C-376/98, Germany v European Parliament and Council, $\$ \$$ 93-107), and consistently applied ever since to competence disputes.

${ }^{66}$ Gauweiler, supra n. 21, $\$ \$ 66-92 ;$ Weiss, supra n. 22, $\$ \$ 29-44, \$ 91$.

${ }^{67}$ Weiss, supra n. 22, $\$ 60$.

${ }^{68}$ For the Court, 'an economic [or monetary] policy measure cannot be treated as equivalent to a monetary [or economic] policy measure for the sole reason that it may have indirect effects on the stability of the euro [or effects that can also be sought in the context of economic policy]' (Pringle, supra n. 65, $\$ 56$; Weiss, supra n. 22, $\$ 61$; Gawweiler, supra n. 21, $\$ \$ 58-59$ ).

${ }^{69} \mathrm{BVerfG}$, supra n. $19, \$ 119$.

${ }^{70}$ Weiss, supra n. 22, $\$ \$ 62-63$. The Court also insisted on the inevitability of economic sideeffects of monetary programmes ( $\$ \$ 65-66$ ), and warned of the consequences that an overly narrow understanding of tolerable 'indirect effects' might have on the efficiency of the European Central Bank's monetary policy $(\$ 67)$. 
and unable to counter-balance the deferential objective-based approach of the Court of Justice, opening the door for potential competence creep.

\section{The Bundesverfassungsgericht in PSPP: providing ill-designed solutions ...}

As is clear from the above, the Bundesverfassungsgericht in its PSPP ruling expressly disavowed the Court of Justice in finding that PSPP exceeded the European Central Bank's mandate and the Union competences for monetary policy, by spilling over the domaine réservé of States on economic and fiscal policy. Particularly problematic for the Bundesverfassungsgericht was the Court of Justice's strictly purposive and highly deferential approach to competence allocation in the Eurozone, its overall disregard for the matter of impact, and its lack of actual account for the distinction between direct and indirect effects it had itself created. Heavily relying on the principle of proportionality, the PSPP ruling offers an alternative test. Because 'judicial review may not simply accept positions asserted by the ECB without closer scrutiny, ${ }^{71}$ it relies on a much stricter standard of scrutiny. Giving more room to impact analysis, it includes a serious balancing of conflicting interests, ${ }^{72}$ under which economic policy effects resulting from monetary programmes are weighed and balanced 'based on proportionality considerations, against the expected positive contributions to achieving the monetary policy objective the ECB itself has set'. ${ }^{73}$

Effects-based analysis of European Central Bank measures definitely has a certain appeal, for its alleged objectivity and stronger connections with monetary policy 'on the ground'. However, the balancing test proposed by the Bundesverfassungsgericht strongly differs from that traditionally conducted in the context of fundamental rights, and raises serious questions. First, one might wonder if it is at all workable. For very practical reasons relating to both the structure of the European economy and the nature of central banking, it is difficult to strictly classify the many effects of a European Central Bank unconventional programme as either monetary or economic/fiscal. Let us assume that the test was workable. The balancing test suggested by the Bundesverfassungsgericht would need to be conducted against a certain benchmark, beyond which the economic and fiscal effects of a European Central Bank programme outweigh its monetary impact, rendering it ultra vires. One can have doubts as to whether such a

\footnotetext{
${ }^{71}$ Supra n. 3, $\$ 142$.

${ }^{72}$ Ibid., $\$ 138$.

${ }^{73}$ Ibid., $\$ 176$.
} 
benchmark could be identified at all. ${ }^{74}$ Moreover, the ability to precisely measure these effects ex ante can seriously be called into question. Finally, this test amounts to a cost-benefit analysis, in that it balances the potential or actual gains and losses produced by a particular programme. The endeavour is delicate, as the identification of the costs and benefits associated with any policy initiative is inevitably highly subjective and judgmental. This is particularly so with regard to monetary policy, a field characterised by deep uncertainty and controversy and, in the context of the Eurozone, a policy space marked by economic heterogeneity, intellectual diversity and political opposition. ${ }^{75}$

From this perspective, the approach of the Bundesverfassungsgericht in PSPP appears particularly one-sided and inward-looking. ${ }^{76}$ Not only because it solely focuses on the costs, and disregards the positive contribution of PSPP to price stability and the general economic policies in the Union, but also because, by irremediably characterising certain effects as costs and emphasising their negativity, it fails to account for the diversity of views prevailing in the Eurozone (which the European Central Bank, through its Governing Council, synthesises). The impact of PSPP on member states' financing conditions is a revealing example. For the Bundesverfassungsgericht, the overall reduction of government bonds spreads in the Eurozone precipitated by quantitative easing is a cost, because it reduces the impetus for structural reforms and budgetary consolidation, amounts to hidden financial assistance, and contradicts the dogma of national fiscal responsibility and budgetary discipline. But under a different light, that same phenomenon might be seen as a gain. The reduction of spread volatility contributes to strengthening the transmission mechanisms and guaranteeing the unity of the Eurozone's monetary policy. It works towards more sustainable convergence of economic and fiscal conditions in the currency union, and thereby contributes to supporting the general economic policies in the Union (Article 127(1) TFEU). In that sense, it can be seen as reinforcing the soundness of national budgetary policies, and contributing to the objective of cohesion in the Union (Article 3 TEU). From this perspective, the Bundesverfassungsgericht's approach in PSPP sounds somewhat hegemonic (and verging on the ideological), in that it seeks to impose its ordo-liberal views about the political economy of the Eurozone, about the legal architecture of the Economic and Monetary Union, or about the proper understanding of fundamental principles of EU law such as proportionality.

${ }^{74}$ See P. Nicolaides, 'The Judgment of the Federal Constitutional Court of Germany on the Public Sector Asset Purchase Programme of the European Central Bank - Setting an Impossible and Contradictory Test of Proportionality', EULawLive, 15 May 2020.

${ }^{75} \mathrm{See}$ H. James et al., The Euro and the Battle of Ideas (Princeton University Press 2016).

${ }^{76}$ See F. Mayer, 'Auf dem Weg zum Richterfaustrecht? Zum PSPP-Urteil des BVerfG', Verfassungsblog, 7 May 2020. 
More fundamentally, the ruling of the Bundesverfassungsgericht in PSPP is striking in the way it uses the principle of proportionality to distinguish monetary policy from economic and fiscal policy, and assess PSPP's compliance with the monetary policy mandate of the European Central Bank (Article 127(1) TFEU) and the competence allocation system of the Treaties. Such use of proportionality, central to the Bundesverfassungsgericht's reasoning, sits uneasily with its status under EU law. ${ }^{77}$ According to the system of the Treaties, proportionality is a principle that governs (and limits) the exercise of EU competences (Article 5(4) TEU), whereas their existence is only governed by the principle of conferral. ${ }^{78}$ It is for this very reason that the Court of Justice in Weiss did not mobilise proportionality to determine the true nature of PSPP, but only to assess the lawful use of its conferred competences by the European Central Bank, ${ }^{79}$ after having established the monetary character of PSPP. ${ }^{80}$ But the Bundesverfassungsgericht did not seem to care. Applying the principle of proportionality in the way it did, it conflated an issue of unlawfulness with an issue of lack of competence. ${ }^{81}$ Assuming that proportionality can be relied upon to solve a competence dispute is not only plainly wrong from an EU law perspective, it also sounds dangerous. ${ }^{82}$ Suggesting that the nature of an act is better determined by its alleged beneficial consequences than by the policy field to which it can be attached, or the objective it pursues, goes against the idea of fixed competence divide. Moreover, it implies that to the extent that the EU acted disproportionately, member states would have to be qualified as competent, even in a field which $a$ priori belongs exclusively to the $\mathrm{EU}$, in clear contradiction of the pre-emptive effect with which such exclusive competences are normally endowed (Article 2(1) TFEU).

${ }^{77}$ And interestingly, its status under German constitutional law. In the past, the Bundesverfassungsgericht has never relied on the principle of proportionality to arbitrate competence conflicts within the German federal system. See, most notably, BVerfG 22 May 1990, 2 BvG 1/88 (Kalkar II), $\$ 105$. On this point, Wendel concludes, following a compelling argument that 'the fact that the Bundesverfassungsgericht insists on proportionality as an instrument for delimiting competences not only cannot be explained by the peculiarities of German constitutional law, but even directly contradicts them': M. Wendel, 'Paradoxes of Ultra-Vires Review - A Critical Review of the PSPP Decision and its Initial Reception', 21 German Law Journal (2020) p. 979 at p. 988.

${ }^{78}$ Along similar lines, see T. Marzal, 'Is the BVerfG PSPP Decision "Simply not Comprehensible"?', Verfassungsblog, 9 May 2020.

${ }^{79}$ Weiss, supra n. 22, $\$ \$ 71-100$.

${ }^{80}$ Ibid., $\$ \$ 46-70$

${ }^{81}$ In doing so, it significantly widens the scope of its ultra vires review, turning it into a general legality review. On this point, see Wendel, supra n. 77, pp. 985-986.

${ }^{82}$ On these dangers, see Editorial Comments, 'Not Mastering the Treaties - The German Federal Constitutional Court's PSPP judgment', 57 CMLR (2020) p. 965 at pp. 972-973. 


\section{The Bundesverfassungsgericht in PSPP: ... but raising actual issues}

In spite of its many methodological flaws, and the amount of controversy it has understandably triggered, the Bundesverfassungsgericht's ruling in PSPP is certainly not one to be taken lightly. Even if it does so in a skewed and confrontational manner, the ruling does raise some real issues, and voices legitimate concerns and pervasive discontent about the Court of Justice's approach to competence allocation in the Economic and Monetary Union, and the European Central Bank's apprehension of its own action. The main strength of the Bundesverfassungsgericht's ruling lies in the way it captures in words a widespread constitutional malaise in the Eurozone. In a post-crisis era, when assessing the constitutionality of its action, it might no longer be sufficient to take the European Central Bank at its word, and blindly trust what it tells us it is doing. It has become increasingly necessary to engage with what it is actually doing, subject its action to stricter scrutiny and ask, beyond assertion, for proof.

We saw that the Bundesverfassungsgericht's rejection of the Court of Justice's conclusions in its PSPP ruling, and its doubts as to the PSPP's legality, are - and wrongly so - based on the principle of proportionality, and an alleged lack of balancing between the costs and benefits of the programme. We showed why such reliance on proportionality to assess the competence of the European Central Bank to adopt a particular programme, and conduct ultra vires review, is unfounded in law. That is not to say that proportionality is irrelevant, but that it should only come second, to assess the exercise of one of its established competences by the EU.

My view is that the Bundesverfassungsgericht's central criticism can be better reconstructed and understood through the prism of the distinction between direct and indirect economic policy effects of monetary policy action. Indeed, this seems to be what is truly at stake in PSPP. In principle, the distinction is to play an important role under the test the Court of Justice carved out in Pringle, Gauweiler and Weiss. The Court has conceived it as the main counter-weight to its overall purposive approach. ${ }^{83}$ But the Luxembourg judges have so far carefully avoided impact analysis, and the distinction has remained but a rhetorical instrument. From this perspective, the German ruling reads as a charge against the Court of Justice for not abiding by its own test in Weiss, for being too dismissive and deferential when it comes to impact analysis, and for failing to take seriously (and thereby downplaying) the question of the directness of the economic effects of PSPP (and that of its true 'centre of gravity'), to solely focus on its proclaimed

\footnotetext{
${ }^{83}$ Again, very much along the lines of how the Court generally proceeds in competence disputes under the 'centre of gravity' doctrine.
} 
objective. ${ }^{84}$ The Bundesverfassungsgericht seems all the more irritated that it had asked the Court of Justice in its preliminary ruling request to further flesh out the concept of indirect effects, and was largely ignored on that point. ${ }^{85}$ Under this light, the PSPP ruling reads as a legitimate 'cry for more methodological integrity. ${ }^{86}$ The Bundesverfassungsgericht also extends this reproach to the European Central Bank itself, which is blamed for not demonstrating sufficient integration of economic impact assessment in its decision-making processes. ${ }^{87}$ There is certainly some truth in this, as the official documentation supporting the Bank's unconventional programmes remains primarily focused on their monetary ambition, rather than on their effects. ${ }^{88}$

\section{On the reactions the PSPP ruling should trigger in Luxembourg and Frankfurt}

From this perspective, the ruling of the Bundesverfassungsgericht in PSPP is not to be dismissed in full. Even if it offers the wrong answers, the German judgment raises legitimate questions, and calls for a strong reaction from the EU, whose institutions (starting with the Court of Justice and the European Central Bank) should rise to the constitutional challenge.

For the Court, the main priority is to reconnect with the spirit of the test it has itself established for assessing European Central Bank compliance with its mandate and the structure of competences in the Economic and Monetary Union. It can do so by complementing teleological analysis with meaningful impact assessment. This will primarily imply further substantiating the distinction between indirect and direct economic policy effects, and taking effects analysis more seriously in its competence assessment of European Central Bank programmes. The Court must engage more forcefully with the content of those

\footnotetext{
${ }^{84}$ In that regard, it is also interesting to note that the proportionality assessment conducted by the Court of Justice in Gauweiler and Weiss primarily focused on the first two conditions of appropriateness and necessity, and only superficially touched upon proportionality stricto sensu (see Gauweiler, supra n. 21, $\$ 91$; Weiss, supra n. 22, $\$ \$ 93-99)$.

${ }^{85}$ This might be a key reason why the Bundesverfassungsgericht chose, in its PSPP ruling, to decidedly turn to proportionality, a principle which had thus far remained rather peripheral in its assessments (be it in its final ruling in the Outright Monetary Transactions case, or even in the PSPP reference). On this point, see Wendel, supra n. 77, pp. 987-988.

${ }^{86} \mathrm{U}$. Sadl, 'When is a Court a Court?', Verfassungsblog, 20 May 2020.

${ }^{87}$ In particular, see supra n. $3, \S 176$.

${ }^{88}$ To take but one example, the decision organising the latest 'pandemic emergency purchase programme' (ECB, Decision No. 2020/440 of 24 March 2020 on a temporary pandemic emergency purchase programme, OJ 2020 L91/1) does not evoke the expected impact of the programme, and its potential economic and fiscal side-effects. Its recitals solely focus on the broader macroeconomic environment, and the monetary objective it pursues.
} 
programmes, the way they are designed and their concrete fallout. It must investigate those effects that most obviously qualify as economic or fiscal, ${ }^{89}$ and examine their magnitude, their position in the chain of causation, and the extent to which they actually affect national economic policy spaces. In that context, regard must be had to the consistency between these effects and the general economic policies pursued in the Union, and how the former can support the latter, in pursuance of Article 127(1) TFEU. The Court should also consider the deliberative processes within the European Central Bank that produce these programmes, and the position effects analysis occupies in that framework (see below). All these elements will be key in the Court's effort to further flesh out the distinction between direct and indirect economic policy effects, and complement purposive inquiry with effects-based analysis. ${ }^{90}$ Second, when assessing the lawfulness of the exercise of the European Central Bank's established competences in the monetary field in the light of the proportionality principle, the Court of Justice must display more thoroughness. ${ }^{91}$ Especially on the third criteria (proportionality stricto sensu), more meaningful scrutiny seems warranted. In the name of European Central Bank independence and discretion, costbenefit analysis remains so far too lightly conducted, so much so that review no longer is credible. This could in our view certainly be remedied by more serious and encompassing cost-benefit analysis. Such analysis would actually look, following a process-oriented approach, at which (potential or actual) economic and monetary advantages and disadvantages associated with a specific programme were taken into account by the European Central Bank, and how meaningfully these various interests were weighed up. More credible review would then be conducted, while preserving the Bank's discretionary space and freedom of action. Overall, it is urgent that the Court of Justice, on the issue of competence and that of lawfulness (where proportionality intervenes), increases the intensity of its review of European Central Bank action, and start to apply a higher standard of scrutiny.

The question of the response that the PSPP ruling calls from the European Central Bank is more delicate. If anything, the Bundesverfassungsgericht's ruling underlines the need for a longer-term reflection within the European Central

\footnotetext{
${ }^{89}$ Most notably in our view, the evolution of States' financing conditions, the impact on the soundness of the banking sector and overall financial stability in the euro area, the effect on growth and overall economic activity, and the amount of cross-country risk-sharing a programme brings with it.

${ }^{90}$ While avoiding most of the pitfalls associated with the proportionality-based approach put forward by the Bundesverfassungsgericht (see supra).

${ }^{91}$ Along similar lines, see A. Bobic and M. Dawson, 'What did the German Constitutional Court get Right in Weiss II?', EULawLive, 12 May 2020.
} 
Bank (already initiated by the 2020 'strategic review') ${ }^{92}$ about the type of monetary policy it wants to conduct, how it wants to conduct it, and how it wants to be seen conducting it. It is high time the European Central Bank started to display more openness and transparency regarding its programmes, the way they are designed and the variables they take into account. More particularly, it is crucial that the European Central Bank, in its public communication and official instruments, now openly and explicitly embraces the economic and fiscal impact of its monetary programmes. ${ }^{93}$ That would primarily mean showing how all economic effects (both 'good' and 'bad') are anticipated and minimised, ${ }^{94}$ in order to guarantee their indirectness (in the sense of their second-order and incidental nature), and the monetary nature of the programme that produced them. This also implies showing how necessary and unavoidable these effects are in the chain of causation leading to the intended monetary effect, how sizeable they are likely to be, and how they weigh against the monetary performance of the programme. Such assessment would be conducted at an overall, Eurozone-wide level, and not along national lines. It would, moreover, be carried out with regard to the course of action the European Central Bank has favoured and the programme it has adopted, while also considering the impact of alternative, counterfactual scenarios (starting with that of 'no action'). Along similar lines, it is even more fundamental that the Bank shows how the economic and fiscal effects associated with its programmes contribute to supporting the general economic policies in the Union (in the spirit of Article 127(1) TFEU). In essence, the European Central Bank would gain by setting out how its monetary action, far from setting a distinct self-established economic policy, fits into the wider economic and fiscal agenda pursued by the Union and its member states, and further strengthens the ability of the Union's political authorities to pursue the policy goals they have set for

${ }^{92}$ ECB Press Release, 'ECB launches review of its monetary policy strategy', 23 January 2020, 〈https://www.ecb.europa.eu/press/pr/date/2020/html/ecb.pr200123 -3b8d9fc08d.en.html〉, visited 23 October 2020.

${ }^{93}$ We know that economic impact assessment of its monetary programmes has constituted standard internal practice within the European Central Bank for some time now. Recent declarations by President Lagarde and Vice-President De Guindos suggest as much. See ECON Committee, Monetary Dialogue with Christine Lagarde (Monday 8 June 2020), p. 4; Exchanges of views between ECB Vice-President de Guindos and the ECON committee, after the presentation of the 2019 Annual Report of the ECB, 7 May 2020, 〈https://onepolicyplace.com/2020/05/07/oppmeeting-summary-ep-econ-committee-exchange-of-views-following-the-presentation-of-the-2019annual-report-by-the-ecb-vice-president-luis-de-guindos-7-may-2020/>, visited 23 October 2020. What we deplore is that such practice is not sufficiently structured, and not meaningfully accounted for in the communication of the European Central Bank, and in the substance of the decision it takes.

${ }^{94}$ Both at the time of the programme's adoption, and throughout its implementation. 
themselves. ${ }^{95}$ Overall, increased transparency would certainly enhance the Bank's accountability, generate more widespread trust in the legality of its action, facilitate external scrutiny, make credible judicial review by the Court of Justice easier, and reassure national constitutional actors which, like the Bundesverfassungsgericht, are wary of competence creep in the Economic and Monetary Union. More fundamentally, a more formalised and structured procedural duty to consider the redistributive effects of the Bank's programmes might alter monetary policy's 'cognitive' structures, influence its content (and efficiency), and contribute to its diversification, if not its democratisation. ${ }^{96}$

\section{The position of the European Central Bank (and national CENTRAL BANKS) IN THE INSTITUTIONAL ARCHITECTURE OF THE ECONOMIC AND MONETARY UNION}

Even though it is most likely that the clash will be resolved in a manner that allows every interested party to save face, the Weiss saga is also symptomatic of the complexity of the European Central Bank's current institutional position within the Economic and Monetary Union, and the tensions that it creates. It perfectly embodies the state of interregnum the Bank has been in since the Eurocrisis, the uncertainties it brings, and the conflicts of authority it has sparked.

The original design of the Economic and Monetary Union as it was established in Maastricht rested on a founding compromise under which the strong independence of the European Central Bank (Article 130 TFEU), and its limited accountability, are directly correlated to a narrow and strictly pre-defined mandate oriented towards price stability. The recent crises, and the action of the Bank over the past decade, have disrupted this equilibrium. They brought about a novel understanding of the European Central Bank's mandate, and precipitated a de facto expansion of its powers, which was not matched by a parallel consolidation of its accountability structures, nor by a renewed modernisation of its independence. ${ }^{97}$ The result is a structural imbalance between the nature and scope of the

\footnotetext{
${ }^{95}$ In establishing the consistency between its monetary action and the broader economic and fiscal agenda of the Union, it is essential that the ECB explicitly relies on those key documents that structure the European Semester process for economic coordination in the Union (starting with the Annual Growth Survey and the economic policy recommendations for the euro area).

${ }^{96}$ In this regard, see I. Feichtner, 'The German Constitutional Court's PSPP Judgment: Impediment and Impetus for the Democratization of Europe', 21 GLJ (2020) p. 1090.

${ }^{97}$ On this phenomenon, see P. Dermine, 'Out of the Comfort Zone? The ECB, Financial Assistance, Independence and Accountability', 26 Mastricht Journal of European and Comparative Law (2019) p. 108 at p. 119-121; F. Amtenbrink, 'The European Central Bank's Intricate Independence Versus Accountability Conundrum in the Post-crisis Governance Framework', 26 Maastricht Journal of European and Comparative Law (2019) p. 165.
} 
European Central Bank's powers, and the scrutiny it can effectively be subject to. This imbalance weakens the constitutional credentials of the Eurosystem, and increases the potential for contestation in its midst.

The PSPP ruling stands as the most direct attempt since the European Central Bank initiated its metamorphosis, to take it out of its 'splendid isolation' and subject it to much stronger forms of accountability. PSPP reads as an implicit call for more institutional maturity through accountability structures consonant with the magnitude of the Bank's powers. It thereby raises the crucial question of the European Central Bank's answerability, and of its subjection, as a constitutional organ holding public authority, to external scrutiny. However, the course outlined by the Bundesverfassungsgericht, and the accountability channel suggested, seems deeply skewed, for two main reasons.

First, the PSPP ruling embodies an approach to European Central Bank accountability which heavily relies on national channels. Beyond obvious problems of consistency and efficiency, such an approach is at odds with the founding idea according to which State equality and the overall interest of the Eurozone are best preserved if accountability within the Eurosystem is carried out at the supranational level. In particular, this approach carries the risk that monetary policy becomes captured by certain national interests, models or traditions, thereby jeopardising the Eurosystem's independence, the status of the single currency as a collective good, and that of monetary policy as an exclusive competence of the Union. From that perspective, the idea of a national government and parliament being forced by their constitutional court to request guarantees from the European Central Bank as to the proportionality of one of its unconventional programme is particularly disturbing. The principle of the Bank's independence has always been a bit of an oddity from a democratic perspective, even more so in these days of unconventional monetary policy. But if new channels of accountability and public scrutiny certainly ought to be explored, and a novel pattern of democratic legitimation be brought about, this should primarily occur at the supranational level, not in individual member states.

The PSPP ruling is also illustrative of the difficult institutional position that national central banks hold under the Eurosystem. Within such a complex, multi-level framework, national central banks indeed enjoy a dual, hybrid status. On the one hand, they constitute the sub-units in an integrated European administrative system managed by the European Central Bank, which they find themselves subordinated to. But on the other hand, they remain national public bodies, historically part of wider national institutional systems, and subject in that framework to a set of country-specific constraints. As a result, they find themselves bound by multiple loyalties, and inserted in different systems of values and priorities. As made perfectly clear in the case of the PSPP ruling and its impact on the Bundesbank, this might present these bodies with conflicting duties and obligations, and expose them 
to competing influences and constraints, flowing from their belonging to supranational schemes and their continued status as national public institutions.

Second, the PSPP ruling stands for an approach under which European Central Bank accountability is first and foremost guaranteed by courts. From this perspective, the ruling of the Bundesverfassungsgericht is but the latest manifestation of a wider trend following which the scrutiny of European Central Bank action has become dominated by judicial organs, for the very reason that political oversight is limited by the strict understanding of the Bank's independence that the Treaties consecrate. This phenomenon begs important questions as to the methods and standards through which judicial review of European Central Bank action should be conducted, the level of deference the Bank should be granted, and how far courts should go in examining - and second-guessing the policy choices it makes. ${ }^{98}$ The clash between the Court of Justice and the Bundesverfassungsgericht in PSPP on the appropriate standard of scrutiny and the proper compromise between effective judicial protection and European Central Bank independence and discretion, is but a painful reminder of how controversial these issues are. More fundamentally, this episode should also prompt a deeper reflection about the actual meaningfulness of such a judge-dominated model of European Central Bank oversight, its ability to effectively compensate for the lack of genuine political accountability, and its overall legitimacy. Do courts, either national or European, constitute the most appropriate fora to scrutinise the action of the European Central Bank and the far-reaching redistributive impact it has on European economies and societies? Is it not a political exercise which should be best left to political, representative institutions? This is probably the most essential question one is left with after reading the PSPP ruling.

\section{THE WIDER TRAJECTORY OF EUROZONE INTEGRATION AND THE FUTURE OF THE FISCAL PILLAR}

As the expression goes, the euro was established as a currency without a State. Despite substantial efforts of correction over the past decade, the Economic and Monetary Union remains a deeply asymmetric currency union, whose highly integrated monetary pillar is flanked by a weak, inefficient economic and fiscal pillar. An important consequence of this persisting asymmetry is that monetary policy stands as the 'main game in town' when it comes to weathering the effects of an economic shock at Eurozone level. In crisis situations, pressure

\footnotetext{
${ }^{98}$ In general, on that matter, see V. Borger, 'Central Bank Independence, Discretion and Judicial Review', in J. Mendes (ed.), EU Executive Discretion and the Limits of Law (Oxford University Press 2019) p. 118.
} 
predominantly lies on the shoulders of the European Central Bank, which over time has emerged as the true guardian of the single currency and of the Eurozone's unity. That status was acquired during the sovereign debt crisis, but the recent pandemic, and the unprecedented recession that ensued, has confirmed the European Central Bank in this existential role. Such an evolution was only possible through legal acrobatics, an expansive reading of the Bank's mandate, and a generous understanding of the principles and prohibitions governing its powers. ${ }^{99}$ This new monetary normality, best embodied by the European Central Bank's unconventional policy of the past decade, attracted criticism from the outset, with politicians, economists and other intellectuals from many different sides expressing their growing discomfort with, or stark opposition to, the rise in power of the European Central Bank. With the PSPP ruling, resistance has further escalated. For the first time, a major constitutional player explicitly denounces the Bank's metamorphosis, and vocally reasserts the limits placed upon its powers. From this perspective, the PSPP ruling might constitute a turning point, in at least two ways.

The first, most straightforward, consequence of PSPP is that it will most probably put a halt to the continued expansion of the powers of the European Central Bank that the Eurozone has witnessed over the past ten years. It is a fact that, from the original securities markets programme to the outright monetary transactions programme, PSPP and now the pandemic emergency purchase programme, the Bank's bond-buying programmes have only grown in size and scope, and been subject to looser eligibility regimes. The PSPP ruling will probably not shrink the Bank's powers, nor will it precipitate a return to the pre-crisis situation. It signals, however, that the Bank's unconventional monetary policy might have reached the outer edge of what is constitutionally possible under the current Treaty framework. This will in turn affect the European Central Bank's ability to react to future crises. Particularly at stake in that regard is Article 123 TFEU, and the prohibition on monetary financing. Under the approach developed by the Court of Justice in Gawweiler and Weiss, Article 123 TFEU remains complied with if bond-buying on secondary markets by the Eurosystem do not have an equivalent effect as direct purchases on primary markets, ${ }^{100}$ and if safeguards are in place to ensure that purchases remain unforeseeable. ${ }^{101} \mathrm{We}$ saw that the Bundesverfassungsgericht in PSPP broadly supported the Court of Justice's assessment that PSPP did not circumvent the prohibition on monetary financing. The Bundesverfassungsgericht's analysis was also highly critical, and by emphasising

\footnotetext{
${ }^{99}$ For a general overview, see K. Tuori, 'Monetary Policy', in F. Amtenbrink and C. Hermann (eds.), EU Law of the Economic and Monetary Union (Oxford University Press, 2020) p. 615 at p. 686-698.

${ }^{100}$ Gauweiler, supra n. 21, \$97; Weiss, supra n. 22, \$\$109-128.

${ }^{101}$ Gauweiler, supra n. 21, $\$ 100-102$; Weiss, supra n. 22, \$\$ 129-132.
} 
certain safeguards as truly crucial, it drew some red lines that future programmes should not cross. Commentators ${ }^{102}$ have been very quick to argue that, read in this light, PSPP might jeopardise the efficiency of the Bank's action against the economic consequences of the Covid-19 pandemic, by indirectly questioning the legality of the pandemic emergency purchase programme. ${ }^{103}$ Even if the Bundesverfassungsgericht expressly stated that its findings solely concern PSPP, ${ }^{104}$ the ruling can be perceived as implicitly targeting the most recent pandemic emergency purchase programme, and reads as a warning sent to Frankfurt. ${ }^{105}$ Particularly problematic is the fact that this program might be analysed as crossing most of the red lines the Bundesverfassungsgericht drew in PSPP. Some of the safeguards that the Bundesverfassungsgericht deemed crucial are indeed considerably relaxed under the pandemic programme. There are no purchase limits under it. ${ }^{106}$ It relies on a very flexible application of the European Central Bank's capital key to distribute purchase volumes across national central banks. ${ }^{107}$ Eligibility requirements are substantially loosened, and the possibilities for ad hoc waivers are expanded. From Karlsruhe's standpoint, the European Central Bank might now be on the verge of monetary financing. Interestingly, in the direct aftermath of the PSPP ruling, markets did not panic, and maintained their confidence in the Bank, which stayed the course on its monetary action. ${ }^{108}$ But the sword of Damocles is still dangling over the European Central Bank's head, and the next judicial clash might already be in the making.

Second, from a longer-term perspective, the ruling of the Bundesverfassungsgericht in PSPP might also meaningfully contribute to the further development of the economic and fiscal pillar of the Economic and Monetary Union, and to the overall rebalancing of the Eurozone's institutional architecture. The ruling, as a vocal reminder of the constitutional limits of the European Central Bank's action and monetary policy, has also underlined the long-term unsustainability of the status quo and the need for more ambitious action on the fiscal side. For years, the Bank has warned policy-makers about

\footnotetext{
${ }^{102}$ See, for example, A. Engel et al., 'Is this completely M.A.D.? Three views on the ruling of the German FCC on 5 ${ }^{\text {th }}$ May 2020', 3 Nordic Journal of European Law (2020) p. 133.

${ }^{103}$ ECB, Decision No. 2020/440, supra n. 88.

${ }^{104}$ See BVerfG, Press Release No. 32/2020, 5 May 2020.

${ }^{105}$ For an in-depth analysis, see A. Viterbo, 'The PSPP Judgement of the German Federal Constitutional Court: Throwing Sand in the Wheels of the European Central Bank', European Papers, 26 June 2020.

${ }^{106}$ See Recital 6 of the PEPP Decision, supra n. 88.

${ }^{107}$ See Recital 5 of the PEPP Decision, supra n. 88, and Lagarde in ECB Monetary Dialogue, supra n. 93 , p. 10.

${ }^{108}$ As the best testament to this, the ECB decided, on 4 June 2020, to increase the volume of PEPP by an extra $€ 600$ billion, up to $€ 1,350$ billion. See ECB, 'Press Release - Monetary Policy Decisions', 4 June 2020.
} 
the untenable pressure put on monetary policy (especially in crisis situations), and called for a strengthening of the fiscal pillar. So far, these calls had not been answered, and States kept on sub-contracting redistributive policies onto the European Central Bank, because it was the most convenient thing for them to do. But the PSPP ruling might have brought European leaders to realise that this fragile equilibrium is not sustainable and needs to be transcended. Somewhat counter-intuitively, the Bank would then have found an unexpected ally in the Bundesverfassungsgericht, whose ruling would have provided a new momentum for further fiscal and budgetary integration in Europe. Retrospectively, the PSPP ruling might be read as a wake-up call, which prompted the Union and its member states to overcome their long-standing disagreements on solidarity and redistribution, and progress along the path of fiscal integration.

Admittedly, the argument remains at this stage somewhat speculative. But recent events tend to confirm this view. ${ }^{109}$ For weeks, the EU and the member states struggled to show a united front against the Covid-19 pandemic and the economic recession that ensued. Very much along the lines of what we had experienced during the Eurocrisis, they failed to agree on the ambitious and collective fiscal response that this unprecedented test called for. The situation could not be more different today, as member states have just agreed on a recovery programme of $€ 750$ billion, ${ }^{110}$ and managed to overcome some enduring taboos within the Eurozone, about fiscal solidarity, joint European debt, or policy conditionality. Of course, those were tough negotiations. They revealed deep political fissures within the Union (most notably between the so-called 'Frugal Four' and integrationist southern States), and stark disagreements as to the key modalities of the programme (grants versus loans, distribution, spending priorities, governance, legal bases). ${ }^{111}$ More fundamentally, we do not yet know whether this breakthrough will remain an ad hoc initiative, or whether it will pave the way for more structural transformations. Nonetheless, it is a fact that EU member states agreed on a plan of a scale and magnitude unheard of in the history of the Eurozone and the Union, which suggests the possibility of a much more integrated economic pillar, and a rebalanced currency union.

${ }^{109}$ For similar views, see J. Komarek, 'Position Paper concerning the BVerfG PSPP Ruling of 5 May 2020 prepared for the standing committee of the House of Representatives of the Netherlands', pp. 5-6; M. Maduro, 'Some Preliminary Remarks on the PSPP Decision of the German Constitutional Court', Verfassungsblog, 6 May 2020; V. Mallet et al., 'The Chain of Events that led to Germany's Change over Europe's Recovery Fund', Financial Times, 22 May 2020.

${ }^{110}$ See European Council, Conclusions of the special meeting of the European Council (17-21 July 2020), 21 July 2020, EUCO 10/20.

${ }^{111}$ For an early assessment, see F. Costamagna and M. Goldmann, 'Constitutional Innovation, Democratic Stagnation? The EU Recovery Plan', Verfassungsblog, 30 May 2020. See also P. Leino, 'Next Generation EU - Breaking a Taboo or Breaking the Law?', CEPS in Brief, 24 June 2020. 
How does one explain such a stark contrast? The main reason is certainly to be found in Berlin, and in the historical turn-around of German Chancellor Angela Merkel, a long-standing 'fiscal hawk' in the Eurozone, in favour of deeper fiscal integration and solidarity in Europe. The abandonment of Germany's entrenched positions about national responsibility and limited burden-sharing paved the way for a Franco-German initiative for a Recovery Fund from 18 May $2020,{ }^{112}$ based on grants, new own resources and joint debt. This joint initiative was swiftly followed by the European Commission with its comprehensive proposal for a new recovery instrument, Next Generation EU. ${ }^{113}$ It would be silly to claim that this is the precise outcome the German judges hoped to bring about. Likewise, we will never know for sure how decisive a factor their PSPP ruling was in Merkel's volte-face in favour of European recovery through fiscal solidarity. ${ }^{114}$ Lawyers and academics should always beware of exaggerating the role of law and judges in political decisions. However, the sequence of events remains intriguing, and must be more than coincidental. By radically exposing the limits of the European Central Bank's action, the continued asymmetry of the Economic and Monetary Union and its long-term unsustainability, PSPP upped the political ante, and precipitated the fundamental changeover towards increased fiscal integration which had been in gestation over the past few years.

The emergence of a stronger fiscal pillar in the Eurozone and the Union will naturally create constitutional difficulties of its own, and might meet strong resistance at the national level. The fact remains that, however counter-intuitive it might seem, the PSPP ruling will have acted as a true catalyst, and triggered a fundamental rethinking of the economic constitution of the Eurozone which was long overdue.

\section{CONCLUDING REMARKS}

The controversy around the PSPP ruling, and the strong opposition it generated, are legitimate and understandable. There are many problematic aspects to this ruling. Its timing was poorly chosen. By questioning some of the most deepseated principles of Union law, it sets a dangerous precedent for the long-term sustainability and efficiency of the EU legal and political system. With regard to

\footnotetext{
${ }^{112}$ See German government, Press Release - A French-German Initiative for the European Recovery from the Coronavirus Crisis, 18 May 2020, 〈https://www.bundesregierung.de/ resource/blob/975226/1753772/414a4b5a1ca91d4f7146eeb2b39ee72b/2020-05-18-deutsch-franzoes ischer-erklaerung-eng-data.pdf?download=1 , visited 23 October 2020.

${ }^{113}$ For a general overview, see European Commission (2020) 'Europe's Moment: Repair and Prepare for the Next Generation' 27 May 2020, 〈https:/ec.europa.eu/commission/presscorner/ detail/en/ip_20_940, , visited 23 October 2020.

${ }^{114}$ For an interesting analysis, see T. Wieder and C. Boutelet, 'Comment Angela Merkel s'est convertie au plan de relance pour éviter l'effondrement de l'Europe', Le Monde, 17 July 2020.
} 
the Eurozone, the ruling reads as particularly one-sided and hegemonic. Whether it is by putting forward a dogmatic understanding of competence allocation in the Economic and Monetary Union, by proposing an alternative test that is both impracticable and without any foundation in EU law, or by favoring an understanding of the European Central Bank's accountability that is nationally driven, PSPP breaks with the logics of trust, cooperation and unity that are supposed to govern the Economic and Monetary Union.

But if the PSPP ruling offers ill-advised - and legally unsound - answers, its main merit lies in the way it captures in (strong) words a growing yet diffuse malaise as to the recent evolution of the Economic and Monetary Union, and the shaky constitutional foundations on which the post-crisis settlement rests. PSPP raises the actual challenges, and asks the right questions. Because this vocal warning emanates from a key institutional player in the European sphere, it will be difficult to ignore, and might act as a wake-up call, precipitating institutional change in the Eurozone. Such catalytic effect should first and foremost be relied upon to bring about a clearer demarcation between economic and monetary policy. To end an uncomfortable feeling of unconstrainedness, there is a need to better frame monetary powers in the Eurozone. This contribution has argued that the best way to do so is not through the principle of proportionality but by combining the current purposive approach with impact analysis, and by forcing the European Central Bank and the Court of Justice to meaningfully consider the question of effects. PSPP also drew our attention to the obsolescence of the Maastricht compromise on the independence and accountability of the European Central Bank, and the wide 'accountability gaps' that past crises have opened. It is yet another painful reminder of the urgency to rethink the principle of the Bank's independence, and match its far-reaching powers with consolidated accountability structures at EU level. Finally, by highlighting the limits of monetary policy, and the chronic asymmetry of our Economic and Monetary Union, PSPP also stands, so we have argued, as an implicit call for a stronger economic pillar, and might have paved the way for the recent successes along the path of deeper fiscal integration.

One might dislike its tone, reject the findings it makes or oppose the alternatives it offers, but the PSPP ruling has all it takes to become a milestone in the history of the Economic and Monetary Union and its law. Not only does it take stock of most constitutional weaknesses and insufficiencies of the Eurozone postcrisis, but it stands as a catalyst for much-needed institutional change, on which the EU and its member states would do well to capitalise. 